\title{
PENGARUH MEDIA PEMBELAJARAN KOMPUTER TERHADAP MINAT BELAJAR SISWA PADA MATA PELAJARAN FISIKA
}

\author{
Zila Razilu \\ Pendidikan Teknologi Informasi, Fakultas Keguruan dan Ilmu Pendidikan, \\ Universitas Muhammadiyah Kendari, \\ Zilarazilu91@gmail.com
}

Abstrak

Peneltian ini bertujuan mengetahui ada tidaknya peningkatan minat belajar siswa pada mata pelajaran Fisika menggunakan media pemebelajaran berbasis komputer Power Point di SMA Muhammadiyah Kendari tahun ajaran 2013/2014. Metode yang digunakan metode eksperimen. Teknik analisis data adalah teknik data kualitatif dengan menggunakan metode eksperimen. Teknik analisis data adalah teknik analisis data kualitatif dengan menggunakan rumus persentase. Hasil analisis data dan pembahasan dapat disimpulkan bahwa penggunaan media pembelajaran berbasis komputer berpengaruh terhadap peningktan minat belajar siswa pada mata pelajaran Fisika di SMA Muhammadiyah Kendari tahun ajaran 2013/2014.

Kata kunci: Pengaruh,Minat,Pembelajaran Berbasis Komputer

\section{PENDAHULUAN}

Perkembangan ilmu pengetahuan dan teknologi yang sangat pesat saat ini menyebabkan hampir semua aktivitas manusia dapat dikendalikan oleh aplikasi ilmu pengetahuan dan teknologi (IPTEK). Dengan semakin berkembangnya ilmu pengetahuan dan teknologi maka diperlukan suatu usaha yang dapat mempermudah mengetahui ilmu-ilmu tersebut( Wiryono dkk.2012). hal ini karena pendidikan merupakan bagian paling utama dalam peningkatkan kualitas sumber daya manusia yang berkompeten, bermartabat dan mampu mengembangkan potensi-potensi yang dimiliki serta ilmu pengetahuan dan teknologi sehingga dapat memunculkan pembaharuan untuk kemajuan bangsa Indonesia. Menurut munir (2008: 52) tujuan pendidikan nasional yang digunakan sekarang secara eksplisit dirumuskan dalam UndangUndang Republik Indonesia No. 20 Tahun 2003 tentang system pendidikan nasional, yaitu pada bab II pasal 3 UU tersebut dijelaskan, bahwa pendidikan nasional berfungsi untuk mengembangkan kemampuan dan membentuk watak sertaperadaban bangsa; dan bertujuan untuk mengembangkan potensi peserta didik agar menjadi manusia yang beriman, dan bertaqwa kepada tuhan yang maha esa, berahlak mulia, sehat, berilmu, cakap, kreatif, mandiri, dan menjadi warga Negara yangdemokratis serta bertanggung jawab;. 
Perkembangan ilmu pengetahuan dan teknologi yang sangat cepat saat ini menuntut suatu Negara meningkatkan kualitas dan mutu pendidikan agar mampu bersaing dengan Negara di dunia. Salah satunya adalah pembelajaran di sekolah yang dituntut untuk dapat selaras dengan perkembangan ilmu pengetahuan dan teknologi.penerapan teknologi dalam proses pembelajaran diharapkan dapat lebih memberikan kemudahan, kemandirian, ketertarikan materi pembelajaran. Pembelajaran di sekolah selain harus selaras dengan perkembangan zaman, dalam proses pembelajaran guru juga dituntut untuk mampu menciptakan suasana belajar yang aktif, inovatif, kreatif, inovatif, kreatif dan menyenangkan. Guru harus mampu membuat proses pembelajaran guru juga dituntut untuk mampu menciptakan suasana belajar yang aktif. Inovatif, kreatif dan menyenangkan. Guru harus mampu membuat proses pembelajaran di kelas itu menarik siswa untuk aktif agar terbentuk interaksi yang baik antara guru, siswa, dan materi pembelajaran yang diajarkan sehingga tidak hanya guru yang menjadi pusat pembelajaran (teacher center learning). Di samping itu, siswa selaku peserta didik berusaha mencari untuk mencari informasi, memecahkan masalah, dan mengemukakan pendapatnya agar proses pembelajaran dikelas dapat berhasil sesuai tujuan pendidikan. Agar proses pembelajaran berhasil salah satunya guru harus menggunakan media pembelajaran yang tepat yang membuat siswa tertarik akan belajar serta dapat menumbuhkan minat belajar didalam diri siswa untuk terus belajar.

Menurut sadiman dkk. (2014: 7) menjelaskan media pembelajaran adalah segala sesuatu yang dapat digunakan untuk menyalurkan pesan dari pengirim ke penerima pesan sehingga dapat merasang pikiran, perasaan, perhatian dan minat siswa sehingga proses belajar dapat terjadi, dengan menggunakan media pembelajaran siswa akan lebih mudah teransang pemikirannya, selain itu media pembelajaran mampu memberikan gambaran yang lebih jelas kepada siswa tentang materi yang sedang dipelajari.

Pada tanggal 9-10 Mei 2014,peneliti telah melakukan wawancara dan observasi, informasi yang didapat dari guru Fisika SMA Muhammadiyah Kendari yaitu ketika pembelajaran Fisika yang dilakukan siswa kurang berantosias dan tidak memperhatikan guru saat menjelaskan serta masi di dominasi menggunakan media pembelajaran tradisional seperti buku cetak dan papan tulis setelah itu guru menjelaskan dan siswa mencatat apa yang dijelaskan oleh guru. Untuk observasi pendahuluan yang dilakukan untuk melihat minat belajar siswa di SMA Muhammadiyah Kendari pada mata pelajaran Fisika. Adapun yang peneliti observasi 
adalah pernyataan suka atau tidak suka siswa pada mata pelajaran Fisika untuk melihat minat belajar Fisika siswa.

Table 1. pernyataan siswa tentang pembelajara Fisika.

\begin{tabular}{|r|c|l|c|}
\hline \multirow{2}{*}{ No } & \multirow{2}{*}{ Kelas } & \multicolumn{2}{|c|}{ pernyataan } \\
\cline { 3 - 4 } & & suka & Tidak suka \\
\hline 1 & $X$ & 9 & 33 \\
\hline 2 & $X I$ & 8 & 36 \\
\hline 3 & XII & 9 & 100 \\
\hline \multicolumn{2}{|c|}{ Jumlah } & 26 & \\
\hline
\end{tabular}

Berdasarkan hasil data wawancara dan observasi di atas menunjukan bahwa terdapat masalah pada minat belajar siswa pada mata pelajaran Fisika di SMA Muhammadiyah Kendari dikarenakan kurang bervariasinya media pembelajaran yang digunakan sehingga tidak menarik perhatian siswa untuk belajar, setelah melihat masalah tersebut, solusi yang dilakukan yaitu dengan cara variasi media pembelajaran yang sesuai dengan perkembangan zaman untuk meningkatkan minat belajar siswa.

Menurut Rudy Bertz dalam sadiman, dkk.( 2014: 20) Rudy Bertz membedakan antara media siar dan rekam sehingga terdapat 8 klasifikasi media yaitu media audio visual diam, media vusual gerak, media audio visual diam, media semi gerak, audio, dan media cetak. Umumnya media pembelajaran yang dikenal adalah video, multimedia interaktif, grafik,flowchart, gambar, power point, poster dan sebagainya. Jenis-jenis media pembelajaran diharapkan dapat diterapkan dalam proses pembelajaran agar proses belajar menjadi lebih mudah, efektif, efisien,menarik,aktif menyenangkan. Sehingga dapat meningkatkan pemahaman siswa tentang materi yang diajarkan dan hasil belajar siswa menjadi lebih baik.

Berdasarkan hal tersebut, dapat diketahui bahwa media pembelajaran visual dengan 8 klarifikasi tersebut merupakan media yang dapat digunakan sebagai media pembelajaran, melalui berbagai program dan aplikasi yang disediakan melalui komputer, guru dapat menciptakan konten pembelajaran yang lebih menarik dan bervariasi untuk siswa lebih berminat dalam belajar, karena sesuai yang dikemukakan oleh Biggs dan Telfer dan Winkel, hal yang berpengaruh dalam belajar adalah ciri khas pribadi,minat,kecakapan,pengalaman dan keinginan belajar (Mujiono dan Dimyanti 2013: 238). Maka minat memiliki pengaruh yang besar terhadap 
belajar. Jika siswa memiliki minat yang rendah terhadap pelajaran fisika maka suda tentu siswa tersebut tidak belajar dengan baik. Dalam pembelajaran banyak media pembelajaran yang dapat diterapkan untuk meningkatkan minat belajar siswa khususnya pada mata pelajaran fisika dan peneliti tertarik menggunakan media berbasis komputer dengan aplikasi Power Point yang memiliki aplikasi menampilkan slide berupa poin materi media yang dipilih karena merupakan salah satu media pembelajaran yang sesuai dengan perkembangan zaman dan mampu menarik perhatian siswa saat belajar sehingga diharapkan munculnya minat belajar siswa khususnya pada mata pelajaran fisika.

Berdasarkan pendapat Daryanto yaitu' contoh roh nyata dari pemanfaatan perkembangan teknologi ini adalah denganpembuatan media pembelajaran yang memanfaatkan program aplikasi Microsoft power point. Program ini memiliki kemampuan yang sangat baik dalam menyajikan sebuah materi dan sudah banyak di gunakan dalam dunia pendidikan. Penggunaan media ini dianggap guru masih menjadi sebuah hal yang menarik perhatian siswa '(Daryanto,2013: 159)

Dilihat uraian diatas bahwa minat belajar merupakan peranan penting, khususnya berpengaruh terhadap keinginan siswa untuk belajar. Hal tersebut bermakna bahwa, semakin tinggi minat seseorang, maka semakin besar pula keinginan siswa dalam belajar. Dalam hal ini peneliti ingin melakukan tes minat belajar siswa di SMA Muhammadiyah Kendari dengan menggunakan media pembelajaran berbasis komputer aplikasi Power Point yang mampu menyajikan materi pembelajaran melalui poin-poin materi yang sesuai dengan perkembangan zaman dan mampu menarik perhatian siswa saat belajar sehingga diharapkan saat belajar minat belajar siswa khususnya pada mata pelajaran Fisika. Maka berangkat dari hal tersubut penulis ingin mengetahui apakah media berbasis komputer dengan aplikasi Power Point berpengaruh terhadap peningkatan minat belajar Fisika siswa. Oleh sebab itu penulis melakukan penelitian dengan judul penelitian "Pengaruh Media Pembelajaran Berbasis Komputer Terhadap Minat Belajar Siswa Pada Mata Pelajaran Fisika SMA Muhammadiyah Kendari Tahun Ajaran 2013/2014".

\section{METODE PENELITIAN}

\subsection{Jenis Penelitian}

Metode penelitian yang digunakan dalam penelitian ini adalah metode penelitian eksperimen. Menurut sugiyono, metode penelitian penelitian eksperimen dapat diartikan sebagai 
metode penelitian yang digunakan untuk mencari pengaruh perlakuan tertentu terhadap kondisi yang terkendalikan (Sugiyono,2016:107).

Metode penelitian eksperimen memiliki bermacam-macam jenis desain penelitian. Desain penelitian ini adalah penelitian eksperimen menggnakan bentuk desain True Experimental design yaitu (eksperimen yang betul-betul), karena dalam desain ini, peneliti dapat mengontrol semua variabel luar yang mempengaruhi jalannya eksperimen (Sugiyono,2016:112). Dengan bentuk One-Shot Case Study adapun bentuknya desain penelitian dapat dilihat yaitu :

Tabel 1. Desain Penelitian

$\mathrm{X} \quad \mathrm{O}$

$\mathrm{X}=$ Data kelompok yang diberi perlakuan media Power Point $\mathrm{O}=$ Observasi

(Sugiyono, 2016: 112).

\subsection{Sumber Data}

Populasi pada penelitian ini adalah seluruh siswa SMA Muhammadiyah Kendari Tahun Ajaran 2013/2014. Teknik sampling yang digunakan dalam penelitian ini adalah simple randon sampling. Menurut sugiyono (2016: 120) simple randon sampling yaitu pengambilan anggota sampel dari populasi yang dilakukan secara acak tanpa memperhatikan strata yang ada dalam populasi.

Adapun teknik sampling dalam penelitian yang digunakan probability sampling jenis simpel random sampling cara yang digunakan dalam pengambilan sampel in dengan 3 cara (1) cara undi (2) cara ordinal (3) randomisasi dari tabel bilangan random ( Margono,2007: 125). Cara yang dipilih untuk menentukan anggota sampel pada penelitian ini dilakukan menggunakan cara undian secara acak yang memberikan kesempata yang sama pada seluruh siswa untuk menjadi anggota sampel peneitian. Jika subjek besar atau lebih dari 100 dapat 10\% - 15\% atau $20 \%$ - 25\% atau lebih. Sampel dalam populasi ini diambil sebesar 25\% dari seluruh siswa SMA

Muhammadiyah Kendari dengan perhitungan yang sudah ditentukan peneliti $\frac{25 \%}{100} \times 104=26$, jadi 26 siswa jumlah sampel tersebut dapat dilihat pada tabel berikut ini : 
Tabel 2. Jumlah Anggota Sampel Siswa

\begin{tabular}{|c|c|c|c|}
\hline Nomor & Putra & Putri & Jumlah \\
\hline 1 & 7 & 6 & 13 \\
\hline 2 & 5 & 8 & 13 \\
\hline Jumlah & \multicolumn{3}{|r}{} \\
\hline
\end{tabular}

\subsection{Tehnik Pengumpulan Data}

Teknik pengambilan data yang digunakan dalam penelitian ini adalah teknik observasi, teknik wawancara, teknik angket, teknik dokumentasi, dan teknik kepustakaan. Ada beberapa teknik pengumpulan data yang peneliti gunakan dalam penelitian, diantaranya :

\subsubsection{Observasi}

Margono (2007: 158) mengemukakan bahwa, observasi diartikan sebagai pengamatan dan pencatatan secara sistematik terhadap gejala yang tampak pada objek penelitian Sutrisno Hadi (1986) mengemukakan bahwa observasi merupaka suatu proses yang kompleks, suatu proses yang tersusn dari berbagai proses biologis dan psikologis (Sutrisno Hadi dalam Sugiyono, 2016: 203). Teknik observasi dalam penelitian ini dilakukan dengan cara mengadakan pengmatan langsung pada proses belajar dan pembelajaran di SMA Muhammadiyah Kendari.

\subsubsection{Wawancara}

Secara sederhana, wawancara dapat dikatakan sebagai suatu percakapan yang dilakukan untuk mengetahui suatu hal ataupun informasi. Lebih lanjut (Moleang, 2011:186) mengatakan bahwa bercakapan itu dilakukan oleh kedua belah pihak yaitu pewawancara (interviewer)yang menggunakan pertanyaan dan terwawancara (interviewee)yang memberikan jawaban atas pertanyaan tersebut. Sementara itu, menurut Sugiyono (2016: 317) wawancara digunakann sebagai teknik pengmpulan data apabila peneliti ingin melakukan studi pendahuluan untuk menemukan permasalahan yang harus diteliti dan jumlah responden. Dalam penelitian ini, teknik wawancara digunakan untuk memperoleh informasi tentang minat belajar siswa pada Mata Pelajaran Fisika.

\subsubsection{Angket}

Sugiyono (2016: 199) Angket merupakan teknik pengumpulan data yag dilakukan dengan cara memberi seperangkat pertanyaan atau pertanyaan tertulis kepada responden untuk dijawabnya. Angket dalam penelitian ini digunakan untuk mendapatkan data mengenai minat belajar siswa pada mata Pelajaran Fisika. Adapun angket atau kuesioner yang digunakan dalam 
penelitian adalah 16 butir pertanyaan yang dikembangkan berdasarkan indikator-indikator minat belajar siswa yang meliputi perhatian, perasaan senang, aktivitas belajar dan kesadaran belajar. Angket yang digunakan dalam penelitian ini adalah dengan skala pengukuran skala likert dengan bentuk checklist lima point. Menurut Sugiyono (2016: 134-135) skala likert digunakan untuk mengukur sikap, pendapat, dan persepsi seseorang atau kelompok orang tentang fenomena sosial ini telah ditetapkan secara spesifik oleh peneliti, yang selanjutnya, disebut varibel penelitian. Dengan kata lain skala likert, maka variabel yang diukur dijabarkan menjadi indikator variabel. Kemudian indikator tersebut dijadikan sebagai titik tolak ukurn untuk menyusun item-item instrumen yang dapat berupa pernyataa atau pertanyaan yang akan dijawab oleh reponden.

\subsubsection{Dokumentasi}

Menurut Margono (2007:181), "teknik dokumentar atau studi dokumentar adalah cara mengumpulkan data melalu peninggalan tertulis, seperti arip-arsip dan termasuk juga buku-buku tentang pendapat, teori, dalil atau hukum-hukum, dan lain-lain yang berhubungan dengan masalah penelitian. Pada penelitian ini teknik dokumentasi dilakukan dengan cara mengambil data yang sudah ada pada sekolah, seperti data siswa SMA Muhammadiyah Kendari Tahun Ajaran 2014/2015.

\subsubsection{Kepustakaan}

Teknik ini digunakan untuk mendapatkan data-data yang berhubungan dengan penulisan dalam penelitian ini, seperti: teori yang mendukung, konsep-konsep dalam penelitian, serta datadata yang pendukung yang diambil dari berbagai referensi

Uji validitas instrumen dalam penelitian ini menggunakan Uji product moment pearson dengan taraf signifikan 5\% dan jumlah murid atau $n=25$ jadi $r_{\text {tabel }}$ sebesar 26 . kriteria uji jika $\mathrm{r}_{\text {hitung }} \quad \mathrm{r}_{\text {tabel }}$ maka butir soal $\sqsubset$ rsebut dinyatkan valid. Perhitungan uji validitas instrumen peneliti dilakukan secara manual, selain itu juga peneliti menggunakan bantuan program Microsoft Excel 2007. Setelah dilakukan uji validitas,selanjutnya dilakukan uji reliabilitas instrumen. Uji reliabilitas dilakukan untuk mengetahui apakah butir pertanyaan kuesioner yang akan digunakan tersebut reliabel (konsisten) atau tidak. Uji reliabilitas yang digunakan dalam penelitian ini adalah uji reliabilitas soal dengan menggunakan rumus Alpa Cronbach. 


\section{$2.4 \quad$ 2Teknik Analisi Data}

Teknik analisi data dalam penelitian ini menggunakan teknik analisis data kualitatif dengan data yang diperoleh adalah berupa skor minat belajar siswa. Adapun pengkategori skor minat belajar ditentukan berdasarkan rentang skor yang telah dibuat, kemudian skor siswa dikelompokkan ke dalam kategori yang sudah ditentukkan. Kategori minat belajar siswa adalah seperti dibawah ini :

Tabel 3. Skor Kategori Minat Belajar Siswa

\begin{tabular}{|l|l|l|}
\hline No & Skor & Kategori \\
\hline 1 & $76-100$ & Sangat Berminat $(\mathrm{SB})$ \\
\hline 2 & $51-75$ & Berminat $(\mathrm{B})$ \\
\hline 3 & $26-50$ & Kurang Berminat $(\mathrm{KB})$ \\
\hline 4 & $0-25$ & Tidak Berminat $(\mathrm{TB})$ \\
\hline
\end{tabular}

Setelah ada skor minat belajar siswa diperoleh dilakukan analisis data untuk melihat apakah ada peningkatan minat belajar siswa yang telah diajarkan menggunakan media Power Pointmenggunakan rumus presentase. Tujuannya untuk mengetahui ada tidaknya peningkatan minat belajar siswa menggunakan media pembelajaran Power Point. Adapun rumus statistika yang digunakan adalah sebagai berikut $p \frac{F}{N} x 100 \%$ (Anas Sujiono, 2004:43).

\section{HASIL DAN PEMBAHASAN}

\subsection{Hasil Penelitian}

Penelitian ini dilaksanakan pada tanggal 11 - 12 Juni 2014. Populasi penelitian, peneiti menggunakan seluruh siswa SMA Muhammadiyah Kendari. Pelaksanaan penelitian ini terbagi dalam dua tahapan, yaitu tahap penelitian dan tahap inti penelitian. Tahap penelitian pendahuluan dilakukan dengan teknik observasi dan wawancara. Tahap inti penelitian dilakukan satu kali menyebar angket kepada seluruh kelas sampel penelitian. Angket tersebut digunakan untuk memperoleh data atau skor minat belajar siswa, terlebih dahulu angket diuji cobakan pada 26 siswa untuk mengetahui validitas dan reliabilitas angket tersebut.

Berdasarkan hasil perhitungan validitas terhadap pernyataan kuisioner yang berjumlah 11 orang pernyataan, yang keseluruhannya adalah pernyataan positif dapat dinyatakan bahwa 11 pernyataan tersebut adalah valid. Selanjutnya hal ini, 11 pernyatan angket tersebut dapat digunakan. Uji reliabilitas dari pernyataan kuisioner minat belajar siswa diperoleh uji reliabilitas 
seluruh kelas SMA Muhammadiyah Kendari adalah 0,83. Apabila dilihat dalam kriteria reliabilitas maka terletak antara $0,80<\mathrm{r} 11<1,00$ yang berarti memiliki kriteria.

Setelah melakukan uji validitas dan relibialitas untuk melihat kecocokkan angket minat belajar yang digunakan selanjutnya dilakukan uji analisis data untuk melihat peningkatan minat belajar disetiap pertemuannya menggunakan tabel kategori yang sudah ditentukan oleh peneliti dan selanjutnya menggunakan rumus persentase untuk mengetahui berapa persen peningkatan minat belajar dan siswa, diperoleh hasil yaitu :

Tabel 4. Data Pencapaian Skor Pertemuan Pertama Minat Siswa Berdasarkan Kategori

\begin{tabular}{|l|l|c|c|}
\hline No & \multicolumn{1}{|c|}{ Skor } & Kategori & $\begin{array}{l}\text { Frekuensi } \\
\text { (Siswa) }\end{array}$ \\
\hline 1 & $76-100$ & Sangat Berminat $(S B)$ & 0 \\
\hline 2 & $51-75$ & Berminat $(B)$ & 11 \\
\hline 3 & $26-50$ & Kurang Berminat $($ KB) & 15 \\
\hline 4 & $0-25$ & Tidak Berminat $(T B)$ & 0 \\
\hline & & Jumlah & 26 \\
\hline
\end{tabular}

Dari data tabel yang dijabarkan di atas dapat dilihat, tabel ini menjabarkan data skor minat berdasarkan kategori skor minat menurut (Sary Yessy, 2015:102) dimana kategori minat belajar dikelompokkan berdasarkan skor dan kemudian dikategorikan. Skor minat yang diperoleh oleh siswa dengan jumlah 26 siswa dapat disimpulkan bahwa dari 26 siswa yang telah diberi perlakuan yang dalam kategori Berminat (B) memiliki frekuensi terbanyak 11 orang siswa dan Kurang Berminat (KB) memiliki frekuensi 15 orang.

Tabel 5. Data Pencapaian Skor Pertemuan Kedua Minat Berdasarkan Kategori

\begin{tabular}{|l|l|c|c|}
\hline No & Skor & Kategori & $\begin{array}{c}\text { Frekuensi } \\
\text { (Siswa) }\end{array}$ \\
\hline 1 & $76-100$ & Sangat Berminat (SB) & 8 \\
\hline 2 & $51-75$ & Berminat (B) & 15 \\
\hline 3 & $26-50$ & Kurang Berminat (KB) & 3 \\
\hline 4 & $0-25$ & Tidak Berminat (TB) & 0 \\
\hline \multicolumn{2}{|c|}{ Jumlah } & 26 \\
\hline
\end{tabular}


Dari data tabel yang dijabarkan di atas dapat dilihat, tabel ini menjabarkan data skor minat berdasarkan kategori skor menurut (Sary Yessy, 2015 : 102) dimana kategori minat belajar dikelompokkan berdasarkan skor dan kemudian dikategorikan. Skor minat yang diperoleh oleh siswa dengan jumlah 26 siswa dapat disimpulkan bahwa dari 26 siswa yang telah diberi perlakuan yang tergolong dalam Sangat Berminat (SB) memiliki frekuensi sebanyak 8, kategori Berminat (B) memiliki frekuensi terbanyak 15 orang siswa dan Kurang Berminat (KB) memiliki frekuensi 3 orang.

Tabel 6. Data Pencapaian Skor Pertemuan Ketiga Minat Berdasarkan Kategori

\begin{tabular}{|l|l|c|c|}
\hline No & Skor & Kategori & $\begin{array}{l}\text { Frekuensi } \\
\text { (Siswa) }\end{array}$ \\
\hline 1 & $76-100$ & Sangat Berminat (SB) & 22 \\
\hline 2 & $51-75$ & Berminat (B) & 4 \\
\hline 3 & $26-50$ & Kurang Berminat (KB) & 0 \\
\hline 4 & $0-25$ & Tidak Berminat (TB) & 0 \\
\hline \multicolumn{3}{|r|}{ Jumlah } & 26 \\
\hline
\end{tabular}

\subsection{Pembahasan Penelitian}

Hasil penelitian di atas dapat dilihat dari data tabel, tabel ini menjabarkan data skor minat berdasarkan kategori skor menurut (Sary Yessy, 2015 : 102) dimana kategori minat belajar dikelompokkan berdasarkan skor dan kemudian dikategorikan. Skor minat yang diperoleh oleh siswa dengan jumlah 26 siswa dapat disimpulkan bahwa dari 26 siswa yang telah diberi perlakuan yang tergolong dalam Sangat Berminat (SB) memiliki frekuensi sebanyak 22, kategori Berminat (B) memiliki frekuensi terbanyak 4 orang siswa dan Kurang Berminat (KB) memiliki frekuensi 0 orang.

Diketahui dari penjelasan diatas bahwa terdapat peningkatan pada minat belajar siswa setelah diberikan perlakuan dengan penggunaan media pembelajaranberbasis komputer Power Point disetiap pertemuannya. Data tersebut selanjutya diolah melalui perhitungan rumus presentase menurut pendapat Anas Sujiono yang diakatakan bahwasannya frekunsi siswa pada minat belajar tertentu dibagi dengan jumlah seluruh siswa yang dikemudian di kalikan dengan 100\% dari 26 siswa yang sudah dikategorikan. 
Data test pertama yang telah dihitung bahwa terdapat 11 siswa yag masuk dalam kategori Berminat(B) yang dapat dipresentasekan $78 \%$ dan terdapat 15 siswa yang masuk dalam kategori Kurang Berminat (KB) yang dapat dipresentasekan 22\%. Dari test kedua yang telah dihitung bahwa terdapat 8 siswa yang masuk dalam kategori Sangat Bermnat (SB) yang dapat dipresentasekan sebesar 22\% terdapat 15 siswa yang masuk dalam kategori Berminat (B) yang dapat dipresentasekan sebesar $73 \%$ dan terdapat 3 siswa yang masuk dalam kategori Kurang Berminat $(\mathrm{KB})$ yang dapat dipresentasekan 5\%. Data yang ketiga setalah dihitung bahwa sebanyak 22 siswa yang masuk dalam kategori Sangat Berminat (SB) yang dapat diprentasekan 59\% dan terdapat sebesar 4 siswa yang masuk dalam kategori Berminat (B) yang dapat dipresentasekan $26 \%$.

Selanjutnya setelah melihat adanya peningkatan minat belajar siswa disetiap pertemuannya kemudian peneliti melihat peningkatan disetiap indikator-indikator minat belajar siswa yang telah diberi perlakuan dengan menggunakan media pembelajaran berbasis komputer Power Point yaitu dapat dilihat pada tabel berikut ini :

Tabel 7. Rekapitulasi Pencapaian Skor Perindikator Minat Belajar Siswa

\begin{tabular}{|l|l|l|l|l|}
\hline \multicolumn{5}{|c|}{ Skor Perindikator Minat Belajar Siswa } \\
\hline \multirow{2}{*}{ Indikator } & \multirow{2}{*}{ Skor Harapan } & \multicolumn{3}{|c|}{ Skor yang diperoleh } \\
\cline { 3 - 5 } & & \multicolumn{2}{|c|}{1} & \multicolumn{2}{c|}{2} & 3 \\
\hline 1 & 800 & 540 & 619 & 684 \\
\hline 2 & 800 & 300 & 557 & 617 \\
\hline 3 & 800 & 431 & 516 & 571 \\
\hline 4 & 800 & 364 & 374 & 529 \\
\hline
\end{tabular}

Data diatas menjelaskan jumlah skor perindikator yang diperoleh dari minat belajar siswa disetiap pertemuannya. Selanjutnya data pencapaian perindikator minat belajar siswa dipresentasekan untuk mengetahui seberapa besar peningatan disetiap indikator minat belajar siswa dengan menggunakan rumus presentase. 
Tabel 8. Rekapitulasi Presentase Pencapaian Indikator Minat Belajar Siswa

\begin{tabular}{|c|c|c|l|l|}
\hline \multirow{2}{*}{ No } & \multicolumn{4}{|c|}{ Indikator Minat Belajar Siswa } \\
\cline { 2 - 5 } & 1 & 2 & \multicolumn{1}{|c|}{3} & \multicolumn{1}{c|}{4} \\
\hline Test 1 & $69,05 \%$ & $60.98 \%$ & $58 \%$ & $49,97 \%$ \\
\hline Test 2 & $78,93 \%$ & $73,56 \%$ & $68,38 \%$ & $64,20 \%$ \\
\hline Test 3 & $87,81 \%$ & $79,86 \%$ & $76,09 \%$ & $68,99 \%$ \\
\hline Jumlah & $79,38 \%$ & $71,19 \%$ & $68,17 \%$ & $59,06 \%$ \\
\hline
\end{tabular}

Dilihat dari tiga kali pengukuran minat belajar dengan angket yang telah peneliti lakukan bahwa diketahui bahwa rata-rata pencapaian indikator minat belajar siswa yang didapat dihitung dengan rumus presentase untuk 3 kali pengukuran, dimana dari hasil angket yang di isi dihasilkam data kemudian diolah dengan rumus presentase dan melihat jumlah rata-ratanya dapat dihitung dengan jumlah keseluruhan untuk setiap idikator minat belajar kemudian dibagi tiga kali test yang hasilnya sebagai berikut ; untuk (Indikator 1) sebesar 79,38\%, (indikator 2)sebesar $71,19 \%$, (indikator 3) sebesar 68,17\% (indikator 4) sebesar 59,06\%.

Data tersebut dapat dinyatakan bahwa rata-rata pencapaian indikator belajar yang paling rendah yaitu indikator 4 , dengan demikian penggunaan media berbasis komputer Power Point ini dapat meningkatkan masing-masing indikator belajar.

Berdasarkan hasil uji analisis data dengan menggunakan tabel kategori yang sudah ditentukan oleh peneliti dan rumus persentase tersebut bahwa media pembelajaran berbasis komputer Power Point berpengaruh terhadap peningkatan minat belajar siswa pada Mata Pelajaran Fisika di SMA Muhammadiyah Kendari. Hal ini, dapat dilihat dari tiga kali peneliti memberikan treatment menggunakan media pembelajaran berbasis komputer Power Point yang menghasilkan peningkatan disetiap pertemuannya dan tingkat belajar pun terlihat dari keempat indikator-indikator minat belajar yang mengalami peningkatan disetiap pertemuannya. Hasil tersebut didukung pula oleh pendapat Daryanto (2013: 159) "Contoh nyata dari pemanfaatan perkembangan teknologi ini adalah dengan pembuatan media pembelajaran yang memanfaatkan program apikasi Microsoft Power Point. Program ini memiliki kemampuan yang sangat baik dalam menyajikan sebuah materi dan sudah banyak digunakan dalam dunia pendidikan. Penggunaan media ini dikalangan guru menjadi sebuah hal yang menarik perhatian siswa". Hal tersebut menguntungkan dimana media berbasis komputer Power Point merupakan suatu hal 
yang menarik perhatian siswa dari ketertarikan siswa tersebutlah akan adanya minat belajar siswa sesuai dengan penelitian yang telah dilakukan peneliti.

\section{KESIMPULAN}

Berdasarkan hasil analisis data dan pembahasan media pembelajaran berbasis komputer Power Point berpengaruh pada peningkatan minat belajar siswa SMA Muhammadiyah Kendari Tahun Ajaran 2013/2014. Pengaruh tersebut dapat digambarkan dalam peningkatan minat siswa sebagai berikut :

Minat belajar Fisika siswa terlihat dari 26 siswa yang mengikuti 3 kali test adanya peningkatan minat belajar siswa, test pertama dengan 26 siswa yang mengikuti tes sebanyak 11 siswa dikategorikan Berminat (B) dan sebanyak 15 siswa dikategorikan Kurang Berminat (KB) dengan presentase siswa yang Berminat (B) sebesar 80\% dan persentase siswa yang Kurang Berminat (KB) sebesar 33\%. Test kedua dengan siswa yang mengikuti test sebanyak 8 siswa dikategorikan Sangat Berminat (SB), sebanyak 15 siswa dikategorikan Berminat (B) dan sebanyak 3siswa dikategorikan Kurang Berminat (KB) dengan persentase siswa yang Sangat Berminat (SB) sebesar 22\% persentase siswa yang Berminat (B) sebesar 75\% dan persentase yang Kurang Berminat (KB) sebesar 5\%. Test ketiga dengan 26 siswa mengikuti test sebanyak 22 siswa diaktegorikan Sangat Berminat (SB) dan sebanyak 4 siswa diaktegorikan Berminat (B) dengan persentase siswa yang Sangat Berminat (SB) sebesar 59\% dan persentase siswa yang Berminat (B) sebesar 43\%. Berdasarkan uraian diatas maka penggunaan media pembelajaran berbasis komputer Power Point pada siswa SMA Muhammadiyah Kendari Tahun Ajaran 2013/2014 berpengaruh terhadap peningkatan minat belajar siswa.

\section{UCAPAN TERIMAKASIH}

Alhamdulillah,senantiasa penulis ucapkan sebagai ungkapan syukur atas berkatdan karunia-Nya, sehingga penulis dapat menyelesaikan laporan kemajuan hibah penelitian dosen pemula ini dengan judul.” Pengaruh Media Pembelajaran Berbasis Komputer Terhadap Minat Belajar Siswa Pada Mata Pelajaran Fisika SMA Muhammadiyah Kendari." Ucapan terima kasih tak lupa penulis ucapkan kepada seluruh pihak yang membantu dalam pelaksanaan penelitian ini. Sehubungan dengan itu, penulis mengucapkan terima kasih kepada RISTEKDIKTI melalui pendanahan hibah PDP 2019,LPPM Universitas Muhammadiyah Kendari. 


\section{DAFTAR PUSTAKA}

Anas Sujjono. 2004. Pengantar Statistic Pendidikan. Raja Gravindo Persada. Jakarta

Arsyad, A. 2005. Media Pembelajaran. PT Raja Grafindo, Jakarta

Daryanto. $\quad$ 2013. Media Pembelajaran. Gava Media. Yogyakarta

Dimyanti dan Mudjono. 2013. Belajar dan pembelajaran. Rineka Cipta. Jakarta.

Margono. 2007. Metodologi Penelitian Pendidikan. Rineka Cipta. Jakarta

Munir. 2008. Kurikulum Berbasis Teknologi Informasi Dan Komunikasi. Alfabeta. Bandung.

Sugiyono. 2016. Metode Penelitian Kuantitaf, Kualitatif, Dan R\&D. Alfabeta. Bandung. 